\title{
SIFAT ORGANOLEPTIK NAGET AYAM YANG MENGGUNAKAN TEPUNG KEDELAI SEBAGAI PENGGANTIAN SEBAGIAN DAGING
}

\author{
Yolanda Angel Ratulangi, S. E. Siswosubroto*, Friets Ratulangi, John. E. G. Rompis.
}

Fakultas Peternakan Universitas Sam Ratulangi Manado 95115

\begin{abstract}
ABSTRAK
Penelitian ini bertujuan untuk mengetahui sejauh mana pengaruh penggunaan tepung kedelai sebagai pengganti sebagian daging terhadap sifat organoleptik naget ayam. Bahan yang digunakan dalam penelitian ini adalah daging ayam bagian dada, tepung kedelai, tepung tapioka, susu, serta bumbu-bumbu. Lapisan terluar naget ayam (coating) menggunakan telur dan tepung roti. Metode yang digunakan pada penelitian ini adalah Rancangan Acak Lengkap (RAL) dengan 4 perlakuan dan 35 ulangan. Variabel yang dianalisis pada penelitian ini adalah sifat organoleptik warna, tekstur, aroma, citarasa. Data yang dianalisis menggunakan anova, Apabila terdapat perbedaan antara rataan dilanjutkan dengan uji beda nyata jujur. Hasil penelitian menunjukkan bahwa pengganti tepung kedelai pada sifat mutu organoleptik naget ayam memberikan pengaruh berbeda sangat nyata $(\mathrm{P}<0.01)$ terhadap warna, tekstur, aroma, dan citarasa. Berdasarkan hasil dan pembahasan maka dapat disimpulkan bahwa penggunaan tepung kedelai sebagai pengganti sebagian daging dapat dimanfaatkan hingga perlakuan $20 \mathrm{~g}$ dan dapat diterima panelis secara organoleptik.
\end{abstract}

Kata Kunci: Daging Ayam, Tepung Kedelai, Sifat Organoleptik.

\section{ABSTRACT}

*Korespondensi (corresponding author)

Email: edmund1403@gmail.com
ORGANOLEPTIC

CHARACTERISTICS OF CHICKEN NAGET ENRICHED WITH SOYBEAN MEAL AS A PART OF MEAT REPLACER. The present study was designed to determine the utilization of soybean meal as a part of meat replacer on chicken naget characteristics. Materials used in the study were: breast part chicken meat, soybean meal, tapioca meal, milk, as well as spices. A Completely Randomized Design (CRD) with 4 treatments and 35 replications was used in the present study. Variables measured were: organoleptic characteristics colors, textures, aroma, taste. Tukey test was further employed to analyze treatment differences. Different between treatment(s) was declared at $\mathrm{P}<$ 0.05 . Research results showed that soybean meal as a part of meat replacer on chicken naget gave a significant effect $(\mathrm{P}<0.01)$ on colors, textures, aroma, and taste. It can be concluded that the utilization of soybean meal as a part of meat replacer on chicken naget can be used up to $20 \mathrm{~g}$ and it is organoleptically accepted.

Key Words: Chicken meat, Chicken naget, Soybean meal, Organoleptic characteristics

\section{PENDAHULUAN}

Saat ini masyarakat Indonesia lebih banyak mengenal daging broiler sebagai ayam potong yang biasa dikonsumsi karena memiliki kelebihan seperti kandungan atau nilai gizi yang tinggi sehingga mampu 
memenuhi kebutuhan nutrisi dalam tubuh. Daging pada umumnya memiliki sifat yang mudah rusak sehingga perlu dilakukan pengolahan untuk mempertahankan nilai gizi (Afrianti et al., 2013). Usaha yang perlu dilakukan untuk mempertahankan mutu atau nilai gizinya adalah pengolahan, dan menciptakan variasi produk-produk baru. Beberapa produk olahan dari daging antara lain naget, bakso, sosis, burger dan abon. Selain itu juga, daging ayam dapat diolah dengan cara dimasak, dipanggang, disate dan diasap. Komposisi kimia daging ayam terdiri dari protein $18,6 \%$, lemak $15,06 \%$, air $65,95 \%$, dan abu $0,79 \%$ (Suradi, 2006).

Naget merupakan salah satu bahan olahan pangan yang bersifat siap untuk dimasak dan biasanya dikemas dalam bentuk beku. Naget adalah bentuk produk daging giling yang dibumbui, kemudian diselimuti oleh perekat tepung, pelumuran tepung roti (breading), setelah itu digoreng. Naget ayam umumnya berbentuk pipih, bulat, kotak, atau bentuk lain yang menarik perhatian anak-anak seperti bentuk huruf atau hewan. Produk naget ayam semakin digemari dan tersedia di supermarket dengan jumlah yang relatif banyak dalam berbagai merek dagang, kemasan, citarasa, tekstur, dan harga jual yang terjangkau (Afriani et al., 2008). Penganekaragaman dan pengolahan produk olahan daging perlu dilakukan agar tersedia pilihan-pilihan bagi konsumen untuk memilih produk yang disukai. Pemanfaatan produk nabati yang ditambahkan pada produk olahan daging seperti naget perlu dikaji dan diteliti khususnya tingkat penerimaan terhadap sifat organoleptik dari aspek warna, tekstur, aroma dan citarasa.

Salah satu produk nabati yang dapat dimanfaatkan untuk pembuatan produk olahan daging seperti naget adalah tepung kedelai. Tepung kedelai mempunyai kandungan nutrisi yang bisa melengkapi produk olahan naget. Menurut Adi sarwoto (2007) komposisi kedelai terdiri dari protein 32,2 gram, serat 4,3 gram, lemak 17,7 gram, air 10,2 gram dan energi 400 kkal. Komposisi tersebut menggambarkan suatu keunggulan dari tepung kedelai yakni terdapat pada kandungan nutrisi seperti protein dan kandungan serat pangan. Mawati et al., (2017) melaporkan dalam penelitiannya bahwa penggunaan tepung kedelai mampu meningkatkan kandungan serat pangan. Keunggulan dari tepung kedelai juga terdapat pada kandungan protein, dengan demikian protein yang terdapat pada daging secara simultan bisa digantikan dengan tepung kedelai. Penggantian ini juga sangat bermanfaat dari sisi ekonomis, mengingat tepung kedelai mudah didapat dan relatif murah. Berdasarkan latar belakang di atas maka telah dilakukan penelitian, untuk mengkaji penggunaan tepung kedelai sebagai 
pengganti sebagian daging terhadap sifat organoleptik naget ayam.

\section{MATERI DAN METODE PENELITIAN}

\section{Materi Penelitian}

Bahan. Bahan yang digunakan dalam penelitian ini adalah : daging ayam bagian dada $1800 \mathrm{~g}$, tepung kedelai $200 \mathrm{~g}$, tepung tapioka $750 \mathrm{~g}$, susu $135 \mathrm{~g}$, serta bumbu-bumbu yang terdiri dari bawang putih $110 \mathrm{~g}$, merica bubuk $15 \mathrm{~g}$, penyedap rasa $75 \mathrm{~g}$, garam $2,5 \mathrm{~g}$, air es $325 \mathrm{~g}$, dan kuning telur 10 butir. Lapisan terluar naget ayam (coating) menggunakan telur dan tepung roti.

Alat. Alat-alat yang digunakan dalam penelitian adalah: timbangan analitik, panci, coper, pisau, baki, telenan, sendok, kompor, tusuk gigi, piring kertas, kuisioner, dan alat tulis.

\section{Metode Penelitian dan Rancangan Percobaan}

Rancangan percobaan yang digunakan dalam penelitian ini adalah Rancangan Acak Lengkap (RAL) dengan 5 perlakuan (Steel dan Torrie, 1991) dan 35 ulangan (panelis) dimana pengukuran data organoleptik menggunakan skala hedonik (Soekarto dan Hubeis, 1992).
Adapun formulasi perlakuan subtitusi daging ayam dengan tepung kedelai diatur sebagai berikut:

$\mathrm{T}_{0}=$ Daging ayam $400 \mathrm{~g}$ tanpa tepung kedelai

$\mathrm{T}_{1}=$ Daging ayam $380 \mathrm{~g}$ ditambah dengan $20 \mathrm{~g}$ tepung kedelai

$\mathrm{T}_{2}=$ Daging ayam $360 \mathrm{~g}$ ditambah dengan $40 \mathrm{~g}$ tepung kedelai $\mathrm{T}_{3}=$ Daging ayam $340 \mathrm{~g}$ ditambah dengan $60 \mathrm{~g}$ tepung kedelai $\mathrm{T}_{4}=$ Daging ayam $320 \mathrm{~g}$ ditambah dengan 80 g tepung kedelai

\section{Prosedur Pembuatan Tepung Kedelai}

Tepung kedelai dapat dibuat dengan cara 1). $1 \mathrm{~kg}$ kacang kedelai disortasi untuk memilih kacang kedelai yang baik, membuang benda asing dan kacang kedelai yang rusak, 2). Kemudian kacang kedelai dibersih, 3). Setelah itu, kacang kedelai menggunakan oven dengan suhu $50{ }^{0} \mathrm{C}$ selama 12 jam dan digiling halus dan diayak dengan ayakan 60 mesh sehingga diperoleh tepung kedelai yang halus,

\section{Prosedur Pembuatan Naget}

Pembuatan naget ayam dengan penggantian tepung kedelai dilakukan dengan lima level tepung kedelai yang berbeda yaitu $0,20,40,60$, dan $80 \mathrm{~g}$. 
Tabel 1. Formulasi Naget Ayam Dan Penggatian Tepung Kedelai Pada Level Berbeda

\begin{tabular}{lccccc}
\hline \multirow{2}{*}{ Bahan } & \multicolumn{5}{c}{ Perlakuan } \\
\cline { 2 - 6 } & $\mathrm{T}_{0}$ & $\mathrm{~T}_{1}$ & $\mathrm{~T}_{2}$ & $\mathrm{~T}_{3}$ & $\mathrm{~T}_{4}$ \\
\hline Daging Ayam Broiler (g) & 400 & 380 & 360 & 340 & 320 \\
Tepung Kedelai (g) & 0 & 20 & 40 & 60 & 80 \\
Air Es (g) & 65 & 65 & 65 & 65 & 65 \\
Tepung Tapioca (g) & 150 & 150 & 150 & 150 & 150 \\
Susu bubuk (g) & 27 & 27 & 27 & 27 & 27 \\
Penyedap Rasa (g) & 15 & 15 & 15 & 15 & 15 \\
Merica (g) & 3 & 3 & 3 & 3 & 3 \\
Bawang Putih (g) & 22 & 22 & 22 & 22 & 22 \\
Garam (g) & 0,5 & 0,5 & 0,5 & 0,5 & 0,5 \\
& 682,5 & 682,5 & 682,5 & 682,5 & 682,5 \\
Minyak Goreng (Sendok Makan) & 3 & 3 & 3 & 3 & 3 \\
Telur (Butir) & 2 & 2 & 2 & 2 & 2 \\
\hline
\end{tabular}

Formulasi naget ayam dengan penggantian tepung kedelai secara lengkap tercantum pada Tabel 1.

Daging ayam bagian dada yang telah dipisahkan dari tulang dan kulit, dipotong kecil-kecil kemudian digiling sampai halus. Bumbu-bumbu terdiri dari bawang putih, merica, garam, tepung kedelai, dan tepung tapioka. Daging ayam yang telah digiling dicampur dengan air es, serta bumbu-bumbu yang telah dihaluskan kemudian diblender selama 5 menit. Adonan yang sudah jadi (homogen) dibentuk dengan ukuran yang diinginkan kemudian dikukus dalam air hingga 10 menit.

Variabel yang diamati pada penelitian ini yaitu:

Variabel yang diamati untuk menentukan sifat organoleptik naget ayam yang menggantikan sebagian daging dengan tepung kedelai yaitu: warna, tekstur, aroma, citarasa. Penilaian ini menggunakan uji skala hedonik dengan menggunakan 35 orang panelis tidak terlatih (Soekarto dan Hubeis, 1992). Dengan skor penilaian untuk warna: (1) sangat tidak menarik, (2) tidak menarik, (3) netral, (4) menarik, (5) sangat menarik. Skor tekstur: (1) sangat tidak halus, (2) tidak halus, (3) netral, (4) halus, (5) sangat halus. Skor aroma: (1) sangat tidak suka, (2) tidak suka, (3) netral, (4) suka, (5) sangat suka. Skor citarasa: (1) sangat tidak enak, (2) tidak enak, (3) netral, (4) enak, (5) sangat enak.

\section{Analisa Data}

Data yang diperoleh dari hasil uji organoleptik dianalisis menggunakan analisis keragaman, dan jika perlakuan 
memberikan pengaruh berbeda nyata maka dilanjutkan dengan uji Beda Nyata Jujur (Steel dan Torrie, 1991).

\section{HASIL DAN PEMBAHASAN}

Data rataan hasil pengamatan sifat organoleptik naget ayam yang menggunakan tepung kedelai sebagai pengganti sebagian daging selama penelitian disajikan pada Tabel 2 di bawah ini.

\section{Warna Naget}

Data rataan hasil pengamatan menunjukkan bahwa pengaruh perlakuan terhadap warna naget berada pada kisaran nilai 3,80 (menarik) sampai 4,60 (sangat menarik). Rataan nilai tertinggi 4,60 (sangat menarik) yang diberikan panelis terhadap warna naget ayam terdapat pada perlakuan $400 \mathrm{~g}$ daging ayam tanpa tepung kedelai, dan nilai terendah 3,80 (menarik) terdapat pada perlakuan $320 \mathrm{~g}$ daging ayam ditambah dengan $80 \mathrm{~g}$ tepung kedelai.

Hasil analisis sidik ragam menunjukkan bahwa perlakuan pengganti tepung kedelai memberikan pengaruh berbeda nyata $(\mathrm{P}<0,05)$ terhadap warna naget ayam yang dihasilkan. Berdasarkan hasil uji lanjut dengan uji Beda Nyata Jujur menunjukkan bahwa perlakuan tanpa tepung kedelai $0 \mathrm{~g}$ memberikan pengaruh tidak berbeda nyata $(\mathrm{P}>0,05)$ terhadap perlakuan $20 \mathrm{~g}$, dan $40 \mathrm{~g}$. Tetapi perlakuan tanpa tepung kedelai $0 \mathrm{~g}$ memberikan pengaruh berbeda nyata $(\mathrm{P}<0,05)$ terhadap perlakuan $60 \mathrm{~g}$, dan $80 \mathrm{~g}$. Perlakuan $20 \mathrm{~g}$ memberikan pengaruh tidak berbeda nyata $(\mathrm{P}>0,05)$ terhadap perlakuan $40 \mathrm{~g}$. Namun perlakuan $20 \mathrm{~g}$ memberikan pengaruh berbeda nyata $(\mathrm{P}<0,05)$ terhadap perlakuan $60 \mathrm{~g}$, dan $80 \mathrm{~g}$. Perlakuan $40 \mathrm{~g}$ berbeda nyata $(\mathrm{P}<0,05)$ terhadap $60 \mathrm{~g}$, dan $80 \mathrm{~g}$.

Tabel 2. Rataan Penggunaan Tepung Kedelai Sebagai Pengganti Sebagian Daging Terhadap Sifat Organoleptik Naget Ayam.

\begin{tabular}{llllll}
\hline \multirow{2}{*}{ Variabel } & \multicolumn{5}{c}{ Perlakuan } \\
\cline { 2 - 6 } & T0 & T1 & T2 & T3 & T4 \\
\hline Warna & $4,60^{\mathrm{a}}$ & $4,42^{\mathrm{ab}}$ & $4,22^{\mathrm{b}}$ & $3,85^{\mathrm{c}}$ & $3,80^{\mathrm{c}}$ \\
Tekstur & $3,37^{\mathrm{a}}$ & $3,74^{\mathrm{b}}$ & $4,25^{\mathrm{c}}$ & $4,54^{\mathrm{cd}}$ & $4,68^{\mathrm{d}}$ \\
Aroma & $4,71^{\mathrm{a}}$ & $4,40^{\mathrm{ab}}$ & $4,17^{\mathrm{bc}}$ & $3,97^{\mathrm{cd}}$ & $3,74^{\mathrm{d}}$ \\
Citarasa & $4,77^{\mathrm{a}}$ & $4,31^{\mathrm{b}}$ & $3,85^{\mathrm{c}}$ & $3,71^{\mathrm{c}}$ & $3,60^{\mathrm{c}}$ \\
\hline
\end{tabular}

Keterangan: Superskrip pada baris yang sama menunjukkan berbeda nyata $(\mathrm{P}<0,05)$ 
Selanjutnya perlakuan $60 \mathrm{~g}$ memberikan pengaruh tidak berbeda nyata $(\mathrm{P}>0,05)$ terhadap perlakuan 80 g. Sedangkan perlakuan $80 \mathrm{~g}$ memberikan pengaruh berbeda nyata $(\mathrm{P}<0,05)$ terhadap perlakuan tanpa kedelai $0 \mathrm{~g}, 20 \mathrm{~g}$, dan $40 \mathrm{~g}$, tetapi memberikan pengaruh tidak berbeda nyata $(\mathrm{P}>0,05)$ terhadap perlakuan $60 \mathrm{~g}$.

Dari hasil analisis data menunjukkan bahwa semakin tinggi pengganti level tepung kedelai terhadap daging naget, maka semakin menurun tingkat ketertarikan panelis terhadap warna naget ayam yang disukai. Hal ini di sebabkan karena panelis lebih menyukai warna naget dengan perlakuan warna daging yang lebih dominan, dibanding dengan warna naget yang menggunakan perlakuan 20 - $80 \mathrm{~g}$ tepung kedelai sebagai pengganti daging naget yang dihasilkan selama penggorengan. Penggunaan tepung kedelai mempengaruhi warna naget ayam, semakin tinggi penggunaan tepung kedelai menyebabkan warna naget menjadi coklat keemasan (Budiono, 2007). Hal ini disebabkan karena warna tepung kedelai yang diolah dan digunakan berwarna putih kecoklatan jika dibandingkan dengan tepung tapioka, dan lainnya. Hasil ini sejalan dengan pendapat Surawan (2007), bahwa panelis lebih menyukai warna naget kuning keemasan dibanding dengan warna coklat keemasan. Selanjutnya Soeparno (2005) menyatakan bahwa warna naget ayam dapat berasal dari bahan utamanya yaitu daging, bahan pengisi, bahan pengikat dan bahan-bahan yang ditambahkan. Menurut Lawrie (1996) bahwa warna daging olahan pada pemasakan curing ditentukan oleh warna otot, aktifitas otot, bahan yang ditambahkan, lama pemasakan dan suhu pemasakan/penggorengan. Warna mempengaruhi penerimaan suatu bahan pangan, sebab warna yang menarik akan meningkatkan tingkat kesukaan konsumen. Warna dari naget ayam adalah warna kuning keemasan (Surawan, 2007).

\section{Tekstur Naget}

Data rataan hasil pengamatan menunjukkan bahwa pengaruh perlakuan terhadap takstur naget berada pada kisaran nilai 3,37 (netral) sampai 4,68 (sangat halus). Rataan nilai tertinggi 4,68 (sangat halus) yang diberikan panelis terhadap tekstur naget ayam terdapat pada perlakuan $320 \mathrm{~g}$ daging ayam ditambah dengan $80 \mathrm{~g}$ tepung kedelai, dan nilai terendah 3,37 (netral) terdapat pada perlakuan $400 \mathrm{~g}$ daging ayam tanpa tepung kedelai.

Hasil analisis sidik ragam menunjukkan bahwa perlakuan pengganti tepung kedelai memberikan pengaruh berbeda nyata $(\mathrm{P}<0,05)$ terhadap tekstur yang dihasilkan.

Berdasarkan hasil uji lanjut menggunakan uji beda nyata jujur menunjukkan bahwa perlakuan tanpa 
tepung kedelai $0 \mathrm{~g}$ memberikan pengaruh berbeda nyata $(\mathrm{P}<0,05)$ terhadap perlakuan 20 g, 40 g, 60 g, dan 80 g. Perlakuan 20 g memberikan pengaruh berbeda nyata $(\mathrm{P}<0,05)$ terhadap perlakuan $40 \mathrm{~g}, 60 \mathrm{~g}$, dan $80 \mathrm{~g}$. Perlakuan $40 \mathrm{~g}$ memberikan pengaruh tidak berbeda nyata $(\mathrm{P}>0,05)$ terhadap perlakuan 60 g, dan 80 g. Juga Perlakuan 60 g memberikan pengaruh tidak berbeda nyata $(\mathrm{P}>0,05)$ terhadap perlakuan $80 \mathrm{~g}$. Sedangkan perlakuan $80 \mathrm{~g}$ memberikan pengaruh berbeda nyata $(\mathrm{P}<0,05)$ terhadap perlakuan tanpa tepung kedelai $0 \mathrm{~g}$, dan 20 g. Tetapi memberikan pengaruh tidak berbeda nyata $(\mathrm{P}>0,05)$ terhadap perlakuan $40 \mathrm{~g}$, dan $60 \mathrm{~g}$.

Dari hasil analisis menunjukkan bahwa semakin tinggi level tepung kedelai terhadap daging naget, maka semakin halus tekstur naget ayam. Hal ini disebabkan karena panelis lebih menyukai naget ayam yang bertekstur halus, karena semakin tinggi penambahan tepung kedelai yang digunakan maka semakin halus tekstur naget ayam yang dihasilkan. Namun dari komposisi pembuatan naget pada penelitian ini menggambarkan ada perubahan komposisi daging seiring dengan penambahan tepung kedelai (Carfrades et al., 2000). Dengan kandungan protein yang tinggi pada tepung kedelai diduga inilah yang menyebabkan terjadi perubahan tekstur daging. Menurut Jayadi et al. (2012) tepung kedelai mempunyai kandungan protein tinggi yaitu sebesar $37,57 \%$ protein, dan tepung kedelai memiliki sifat fungsional antara lain sifat pengikatan air dan lemak, sifat mengemulsi dan mengentalkan. Menurut Soeparno (2005) tekstur dan keempukan daging sangat tergantung pada komponen protein yang terikat pada daging tersebut.

\section{Aroma Naget}

Data rataan hasil pengamatan menunjukkan bahwa pengaruh perlakuan terhadap aroma naget berada pada kisaran nilai 3,74 (suka) sampai 4,71 (sangat suka). Rataan nilai tertinggi 4,71 (sangat suka) yang diberikan panelis terhadap aroma naget ayam terdapat pada perlakuan $400 \mathrm{~g}$ daging ayam tanpa tepung kedelai, dan nilai terendah 3,34 (netral) terdapat pada perlakuan $320 \mathrm{~g}$ daging ayam yang ditambah dengan $80 \mathrm{~g}$ tepung kedelai. Data hasil pengamatan menunjukkan terjadi penurunan tingkat kesukaan terhadap aroma naget ayam. Hal ini disebabkan semakin tingginya daging ayam pengganti dengan tepung kedelai, maka tingkat kesukaan terhadap aroma naget ayam semakin menurun.

Berdasarkan hasil analisis sidik ragam menunjukkan bahwa perlakuan pengganti tepung kedelai memberikan pengaruh yang berbeda nyata $(\mathrm{P}<0,05)$ terhadap aroma naget ayam. 
Hasil uji lanjut menggunakan uji beda nyata jujur menunjukkan bahwa perlakuan tanpa tepung kedelai $0 \mathrm{~g}$ memberikan pengaruh tidak berbeda nyata ( $\mathrm{P}>0,05)$ terhadap perlakuan $20 \mathrm{~g}$, dan $40 \mathrm{~g}$. Tetapi perlakuan tanpa tepung kedelai $0 \mathrm{~g}$ memberikan pengaruh berbeda nyata $(\mathrm{P}<0,05)$ terhadap perlakuan $60 \mathrm{~g}$ dan $80 \mathrm{~g}$. Perlakuan $20 \mathrm{~g}$ memberikan pengaruh tidak berbeda nyata $(\mathrm{P}>0,05)$ terhadap perlakuan 40 g. Tetapi perlakuan $20 \mathrm{~g}$ memberikan pengaruh berbeda nyata $(\mathrm{P}<0,05)$ terhadap perlakuan $60 \mathrm{~g}$ dan $80 \mathrm{~g}$. Perlakuan $40 \mathrm{~g}$ memberikan pengaruh tidak berbeda nyata $(\mathrm{P}>0,05)$ terhadap perlakuan $60 \mathrm{~g}$. Tetapi perlakuan $40 \mathrm{~g}$ memberikan pengaruh berbeda nyata $(\mathrm{P}<0,05)$ terhadap perlakuan 80 g. Dan perlakuan 60 g memberikan pengaruh tidak berbeda nyata $(\mathrm{P}>0,05)$ terhadap perlakuan 80 g. Sedangkan perlakuan $80 \mathrm{~g}$ memberikan pengaruh berbeda nyata $(\mathrm{P}<0,05)$ terhadap perlakuan tanpa tepung kedelai 0 g, 20 g, dan 40 g. Tetapi perlakuan $80 \mathrm{~g}$ memberikan pengaruh tidak berbeda nyata $(\mathrm{P}>0,05)$ terhadap perlakuan $60 \mathrm{~g}$.

Penurunan tingkat kesukaan dari pengganti tepung kedelai $20 \mathrm{~g}-80 \mathrm{~g}$ disebabkan karena panelis lebih menyukai aroma naget ayam yang berbau daging dibanding dengan aroma tepung kedelai. Pembuatan tepung kedelai pada penelitian ini telah melalui proses pemanasan. Proses pemanasan dalam pembuatan tepung kedelai mampu mengurangi bau khas yang sering terdapat pada produk kedelai (Thebaudin dan Levebvre, 1997 dalam Yangilar, 2013). Aroma yang muncul dari produk olahan daging biasanya berasal dari bahan pengisi dalam pembuatan produk (Afrianti et al., 2013). Pada penelitian ini selain perlakuan penggantian daging dengan tepung kedelai, bahan pengisi mempunyai komposisi yang sama. Soeparno (2005) menyatakan bahwa aroma yang timbul disebabkan dari kombinasi pembebasan substansi volatile dengan bumbu-bumbu yang dicampur yang akan menimbulkan aroma. Citarasa dan aroma daging penggantian yang kompleks dan saling berkaitan, sedangkan rasa dan aroma daging masak banyak ditentukan oleh prekursor yang larut dalam air dan lemak dan pembebasan pengganti volatile yang terdapat pada daging. Aroma daging masak dipengaruhi oleh umur ternak, spesies jenis kelamin, lemak, bangsa, lama waktu dan kondisi penyimpanan (Soeparno 2005). Menurut Koswara (2010), tepung kedelai mengandung enzim lipoksidase yang menghidrolisis atau mengurai lemak kedelai sehingga menghasilkan senyawa penyebab bau langu (beany flavor), sampai dengan pengganti $80 \mathrm{~g}$ tepung kedelai pada penelitian menunjukkan adanya bau yang khas pada produk naget yang dihasilkan.

\section{Citarasa}


Data rataan hasil pengamatan menunjukkan bahwa pengaruh perlakuan terhadap citarasa naget berada pada kisaran nilai 3,60 (enak) sampai 4,77 (sangat enak). Rataan nilai tertinggi 4,77 (sangat enak) yang diberikan panelis terhadap citarasa naget ayam terdapat pada perlakuan $400 \mathrm{~g}$ daging ayam tanpa tepung kedelai, dan nilai terendah 3,60 (enak) terdapat pada perlakuan $320 \mathrm{~g}$ daging ayam ditambah dengan $80 \mathrm{~g}$ tepung kedelai. Data hasil pengamatan menunjukkan terjadi penurunan tingkat kesukaan terhadap citarasa naget ayam. Hal ini disebabkan semakin tingginya daging ayam dengan pengganti tepung kedelai, maka tingkat kesukaan terhadap citarasa naget ayam semakin menurun.

Hasil analisis sidik ragam menunjukkan bahwa perlakuan pengganti daging ayam dengan tepung kedelai memberikan pengaruh berbeda nyata $(\mathrm{P}<0,05)$ terhadap citarasa naget ayam yang dihasilkan.

Berdasarkan hasil uji lanjut menggunakan uji beda nyata jujur menunjukkan bahwa perlakuan tanpa tepung kedelai 0 g memberikan pengaruh berbeda nyata $(\mathrm{P}<0,05)$ terhadap perlakuan $20 \mathrm{~g}, 40 \mathrm{~g}, 60$ g, dan 80 g. Perlakuan 20 g memberikan pengaruh berbeda nyata $(\mathrm{P}<0,05)$ terhadap perlakuan 40 g, 60 g, dan 80 g. Sedangkan perlakuan $40 \mathrm{~g}$ memberikan pengaruh tidak berbeda nyata $(\mathrm{P}>0,05)$ terhadap perlakuan
$60 \mathrm{~g}$ dan $80 \mathrm{~g}$. Demikian halnya perlakuan $60 \mathrm{~g}$ memberikan pengaruh tidak berbeda nyata $(\mathrm{P}>0,05)$ terhadap perlakuan $80 \mathrm{~g}$. Sedangkan perlakuan $80 \mathrm{~g}$ memberikan pengaruh berbeda nyata $(\mathrm{P}<0,05)$ terhadap perlakuan tanpa tepung kedelai $0 \mathrm{~g}$, dan 20 g. Tetapi perlakuan $80 \mathrm{~g}$ memberikan pengaruh tidak berbeda nyata $(\mathrm{P}>0,05)$ terhadap perlakuan $40 \mathrm{~g}$, dan $60 \mathrm{~g}$.

Naget ayam tanpa pengganti tepung kedelai menunjukkan citarasa yang sangat enak. Hal ini disebabkan, naget ayam tanpa pengganti tepung kedelai $(0 \mathrm{~g})$ merupakan naget ayam yang banyak disukai dengan rasa daging dominan dan rasa bumbu yang cukup dan tidak berlebihan. Rasa naget ayam yang dihasilkan terutama berasal dari bumbu-bumbu yang digunakan selama proses yaitu garam, lada, bawang putih, susu bubuk dan flavor daging selama pemasakan. Hal ini sesuai dengan pendapat Surawan (2007) bahwa citarasa dipengaruhi banyak faktor, antara lain: tekstur, senyawa kimia, suhu, konsentrasi, dan interaksi dengan komponen rasa yang lain.

\section{KESIMPULAN}

Berdasarkan hasil dan pembahasan maka dapat disimpulkan penggunaan tepung kedelai sampai 20 g sebagai pengganti daging ayam (dalam komposisi 
naget $380 \mathrm{~g}$ daging) memberikan sifat organoleptik yang baik.

\section{DAFTAR PUSTAKA}

Adisarwoto, T. 2007. Budidaya dengan Pemupukan yang Efektif dan Pengoptimalan Peran Bintil Akar Kedelai. Penebar Swadaya, Depok

Afriani, H. Lukman, R. Pudji, dan Z. Abdul. 2008. Pengendalian pengolahan chiken naget pada ibu-ibu perkumpulan pengajian di Kelurahan Simpang Tiga Sipin Kecamatan Kota Baru Jambi. Jurnal Pengabdian Pada Masyarakat. 11(3):115-120.

Afrianti, M. B. Dwikola, dan B.E. Setiani. 2013. Perubahan warna, profil protein, dan mutu organoleptik daging ayam broiler setelah direndam dengan ekstrak daun senduduk. Jurnal Aplikasi Teknologi Pangan 2 (3): 116-120

Budiono, I. 2007. Pengaruh Subtitusi Tepung Kedelai Terhadap Kadar Protein, dan Daya Terima Tepung Gaplak Serta Hasil Olahannya. Jurnal Kemas 2 (2): 132.

Carfrades S., M. A. Guerra, J Carballo, F. Martin, and F. Jimenes Colmenero, 2000. Plasama protein and soy fiber content effect on Bologna Saugsage properties as influenced by fat level. J. Food Sci. 65(2): 281-287.

Jayadi, Y, B. Bahar, dan S. Sirajuddin. 2012. Pengaruh Subtitusi Tepung Kedelai Terhadap Penerimaan dan Kandungan Gizi Sakko-Sakko. Media Gizi Masyarakat Indonesia 122-129. http://repository.unhas.ac.id/handl e/123456789/9328

Koswara, 2010. Teknologi Pengolahan Kedelai. Pustaka Sinar Harapan. Jakarta.

Lawrie, R. A. 1996. Ilmu Daging Diterjemahkan Oleh Aminudin Parakkasi A. Penerbit Universitas Indonesia Press, Jakarta.

Mawati, A., E.H.B. Sondakh, J.A.D. Kalele, dan R. Hadju. 2017. Kualitas chicken nugget yang difortifikasi dengan tepung kacang kedelai untuk peningkatan serat pangan (dietary fiber). Jurnal Zootek 37(2): 464-473

Soekarto, S.T. 1985. Penilaian Organoleptik. Bogor: PUSBANGTEPA, IPB Press.

Soeparno, 2005. Ilmu dan Teknologi Daging. Gadjah Mada Uniersity. Cetakan Keempat. Gadjah Mada University Press. Yogyakarta.

Surawan, F. E. D. 2007. Penggunaan tepung terigu, tepung beras, tepung tapioka, dan tepung maizena, terhadap tekstur sifat sensoris fish naget ikan tuna. Jurnal Sain Peternakan Indonesia 2(2): 78-84.

Suradi, K. 2006. Perubahan Sifat Fisik Daging Ayam Post Portem Selama Penyimpanan Suhu Ruang Ilmu Ternak 6 (1): 23-27.

Steel, R. G. D. dan J. H. Torrie. 1991. Prinsip dan Prosedur Statistika. Diterjemahkan oleh Bambang Sumantri.PT. Gramedia Pustaka Utama. Jakarta.

Yangilar, F. 2013. The application of dietary fibre in food industry: structural features, effects on 
health and definition, obtaining and analysis of dietary fibre: A
Review. Journal of Food and Nutrition Research Vol. (3): 13-23 